essentially allied to insanity and insisted that it should be treated medically and not as if it were a crime. It was mainly due to him that the Habitual Drunkards Act of 1888 and the Inebriates Act of 1898 were amended. During the fifty years of its existence, the subjects discussed by the Society have included the influence of heredity on alcoholism, alcoholism and child welfare, alcoholism and venereal disease, the use of alcohol in medicine, drug addiction as an international problem, ether-drinking and the cigarette habit. The Society, which consists of medical members and lay associates, aims at a scientific study of alcoholism and drug addiction, and has not a policy of total abstinence.

\section{Society of Dyers and Colourists}

Arrangements for the jubilee celebrations of the Society of Dyers and Colourists, to be held at Bradford at Whitsuntide, are in active progress. Inaugurated at a meeting in Bradford on May 14, 1884, the Society is the oldest of its kind in Great Britain. Special interest in the celebrations will be attached to the issue early next month of a jubilee number of the Society's Jour. nal, containing original articles by eminent authorities on the processes of dyeing and their development in the course of the past fifty years. In these, invention, scientific research and records of practical applications will receive full attention. It may be recalled here that the Society allots the Perkin Gold Medal at intervals, for conspicuous service to the tinctorial industries. By means of its award the synthesis of indigo, the discovery of viscose, of primuline, and of alizarine blue have been severally recognised.

\section{Geistige Arbeit}

THE object of a new periodical of this title which appears twice monthly (25 pfennigs per copy) is to give brief reviews of the progress and tendencies of modern scientific research. The subjects considered cover a wide field, including anthropology, political economy, agriculture, sociology and all the pure and applied sciences. There are articles on peasants and nomads, problems of German sociology, new concepts of natural science, methods of counting for statistical purposes, Paracelsus (a sketch), and many others. The contributors are chosen from the ranks of those who have done original work in their respective fields. In the article by Möglich dealing with the foundations of present-day physics, we find due acknowledgment paid to the epoch-making ideas of Planck and Heisenberg, but there are important omissions which detract from the value of the account. In highly compressed articles of this type, it is of primary importance that the authors should have not only a deep insight into their subjects but also a proper sense of values, if the services of a discriminating censor are not to be invoked. Goethe has said : "Die Vernunft ist auf das Werdende, der Verstand auf das Gewordene angewiesen". This remark applies particularly aptly to the present journal, which bears the sub-title "Zentralblatt für die gelehrte Welt". The article on Theophrastus Bombastus von Hohenheim, commonly called Paracelsus, is of interest as his name has recently come into prominence again as one of the first great experimenters in medical science-one hears of a Paracelsus Renaissance in Germany-in spite of a certain notoriety as a vagabond miracle-worker which he probably only partly deserved. His ideas, if not actual results obtained, undoubtedly exerted a considerable influence on later workers. The journal is published by Walter de Gruyter and Co., Berlin W.10, Genthinerstr. 38 .

\section{Philosophy of Science}

THe welcome co-operation between science and philosophy, which has become a distinctive feature of our time, is further illustrated by the appearance of a new quarterly, Philosophy of Science, which is published by the Philosophy of Science Association in the United States (Baltimore: Williams and Wilkins Co.; London : Baillière, Tindall and Cox. 6s. $9 d$.). This interesting publication sets itself the useful task of giving an organised expression to the growing interest among philosophers and scientific workers in classifying, and perhaps unifying, the programmes, methods and results of the disciplines of philosophy and of science. With this object in view, the editor, Prof. W. M. Malisoff, proposes as a research programme, the analysis of meaning, symbolism, definition, axioms and postulates, the study of the nature and formulation of theoretical principles, and questions of method and of the structure and hierarchy of the sciences. The first issue of the new journal contains a remarkable series of papers ; among the contributors are Prof. J. B. S. Haldane on "Quantum Mechanics as a Basis for Philosophy", D. J. Struik on "The Foundations of the Theory of Probabilities", Rudolf Carnap on "The Character of Philosophic Problems". The excellent presentation of the journal and the eminence of its contributors give an added value to its object and method which, no doubt, will appeal equally to scientific workers and to philosophers.

\section{Research in the Solomon Islands}

A REPORT on the work of the Templeton-Crocker Expedition to the Solomon Islands, 1933, has recently been sent to Nature by the Director of the Bernice P. Bishop Museum, Honolulu. The expedition left San Francisco on March 2, 1933, in Mr. TempletonCrocker's auxiliary schooner Vaca and returned on September 15 after conducting a preliminary ethnographical and medical survey of a number of islands in the Solomon group. The principal objective was the Rennell and Bellona islands, but before arriving there the expedition collected data bearing on tuberculosis and tropical diseases, as well as ethnographical material, at Sikiana, Tulalagi, Guadalcanar and Malaita. Advantage was taken of conditions on Rennell and Bellona, where bird and insect life are undisturbed and the inhabitants virtually unaffected by European contacts, to make extensive collections of birds, plants and insects and to record particulars relating to native life and customs, which appear to 